\title{
The Effectiveness of Hypno-Eft in Increasing Self confidence and Reducing Public Speaking Anxiety in Vocational High School Students X
}

\author{
Rifdaturahmi ${ }^{\mathrm{a},}$ Hally Weliangan ${ }^{\mathrm{b}}$ \\ a rifdaturahmi@gmail,com; bhallyweliangan07@gmail.com \\ ${ }^{a}$ Gunadarma University, J1. TB Simatupang No.51B, RT.1/RW.8, 12540 South Jakarta, Indonesia \\ ${ }^{\mathrm{b}}$ Gunadarma University, J1. TB Simatupang No.51B, RT.1/RW.8, 12540 South Jakarta, Indonesia
}

\begin{abstract}
Self confidence and public speaking are added values for students, but this is often a frightening specter for students in communicating, discussing and presenting in class. This condition is experienced by many students, especially grade 10 students majoring in office administration at SMK X Jakarta. One way to increase self confidence and reduce public speaking anxiety is through hypno EFT intervention. The purpose of this study was to see the effectiveness of hypno-EFT in increasing self confidence and reducing public speaking anxiety in 10th grade students majoring in office administration at SMK X Jakarta. This study uses an experimental method with a pretest-posttest control group design. The sample in this study was grade 10 students majoring in office administration, SMK X Jakarta with a total of 40 students. Self confidence is measured using a self confidence scale. Public speaking anxiety was measured using the public speaking anxiety scale (PSAS). The data analysis technique used in this study was the independent sample $t$-test. Based on the results of the analysis, it is known that there is a significant difference before and after giving hypno-EFT with significant values for self confidence and public speaking anxiety of 0.000 and 0.000 , respectively $(<0.01)$. These results indicate that the hypothesis that hypno-EFT is effective in increasing self confidence and reducing public speaking anxiety is accepted.
\end{abstract}

Keywords: Self confidence , Public speaking anxiety, hypno-EFT

\section{Introduction}

Vocational High School is education at the secondary level that prioritizes the development of students abilities to carry out certain types of work. Vocational secondary education prioritizes preparing students to enter the workforce and developing professional attitudes. In accordance with its form, Vocational High School organizes educational programs that are tailored to the types of employment (Peraturan Pemerintah Nomor 29 Tahun 1990). According to data from the Ministry of Education and Culture (2021), Indonesia has 14,336 public and private vocational hgh school. For DKI Jakarta, there are 518 state vocational schools and 63 private vocational schools.

One of the private vocational schools in Jakarta is SMK X Jakarta. This school consists of three majors in areas of expertise, namely computer and network engineering, multimedia and office administration (CyberMedia, 2019). These departments in teaching and learning activities use the K-13 curriculum, Rev. The Ministry of Education and Culture (2014) said that in this learning, students carry out learning activities to observe, ask questions, collect information, associate or analyze, and communicate something that has been found in analytical activities. The curriculum encourages students to be active in teaching and learning activities so that they dare to express their opinions. This learning applies to all skill programs or majors at 
SMK X Jakarta, especially for office administration majors. On the website of SMK X Jakarta it is stated that one of the objectives of the competence of the office administration department is to apply and develop oral and written communication skills with relationships by paying attention to norms and the community environment (Cybermedia, 2019).

Based on an interview with a counseling guidance teacher at SMK X Jakarta, it was stated that the office administration major requires good self-confidence and good public speaking skills in order to compete in the world of work. This is because many graduate jobs in office administration require their workers to be able to communicate well individually and in front of many people. The counseling guidance teacher also said that during the learning process the office administration department had many subjects that made presentations or public speaking. Likewise when the final exam, this department has several subjects that are tested with presentations or open discussions which are commonly called public speaking. Public speaking is very necessary, especially for vocational students majoring in office administration, but in reality there are many problems faced by students in discussion and public speaking activities.

The results of interviews conducted by giving open questions to 20 students of SMK X Jakarta from several majors other than class 10 majoring in office administration showed $80 \%$ (16 people) of students chose the learning method by listening and taking notes rather than discussing and then presenting in front of the class. In $70 \%$ (14 people) students were found to experience anxiety such as palpitations, cold sweats, and body shaking. As many as 50\% (10 people) of students said that almost all of their friends in their class experienced the same thing, namely not being confident and experiencing anxiety when speaking in public.

Based on the interview above, it shows that there is self-confidence and public speaking anxiety in students at SMK X Jakarta. Indrawati (2018) says that self-confidence is essential in creating good communication, especially in public speaking. Juwita, Ivan and Rosy (2011) also explain that self-confidence is the initial capital for someone when they want to speak in public. Without self-confidence, something that has been prepared will be lost when it is delivered in front of many people. Confidence will lead to confidence that all the work that will be done can run successfully. In line with the opinion above, Raja (2017) said that lack of self-confidence is the most common reason for fear of public speaking.

Low self-esteem can lead to high anxiety. This is in line with the research conducted by Wahyuni (2011) in his research on the relationship between self-confidence and public speaking anxiety in psychology students who also found that there was a negative relationship between self-confidence and public speaking anxiety. This means that the higher the self-confidence, the lower the anxiety of speaking in public, and vice versa. According to Rakhmat (2009) if someone feels insecure, that person will have difficulty communicating ideas to others, and avoid speaking in public, for fear of being blamed.

Public speaking anxiety in students has been experienced by many. Cherry (2010) said many students reported high levels of public speaking anxiety during presentation assessments. While low levels of anxiety can improve performance, too much anxiety can have a detrimental effect. Often students show it with shaking bodies, cold sweat like nervousness. Bartholomay and Houlihan (2016) suggest that the visible manifestations of public speaking anxiety include nervousness, restlessness, voice shaking when speaking in public, heart palpitations when wanting to do public speaking or before doing public speaking.

The phenomena above show that public speaking anxiety and lack of self-confidence are experienced by many students, especially students. Lack of self-confidence and public speaking anxiety can be overcome with several interventions, one of which is Hypno-EFT (emotional freedom technique). Hypno-EFT according to Gunawan (2012) is a variant of Meridian Based Therapy (MBT) and this therapeutic technique is similar to acupuncture therapy. The difference is that acupuncture uses needles to stimulate energy points scattered in the meridians, while EFT uses fingers to tap energy points with a certain number of beats and in a certain order.

Gunawan (2009) said that several problems that can be solved with Hypno-EFT include anxiety, anger, compulsive behavior, panic disorder, addiction (cigarettes or drugs), stress and depression, trauma, fear or phobia (heights, animals, or other things). certain objects), anxiety in public places, fear of speaking in public, 
headaches or migraines, dispelling negative beliefs, self-confidence problems, feelings of shame or guilt, insomnia, disappointment or hurt, peak performance, sexual problems, problems with children or women, cancer, allergies etc.

Research conducted by Boath, Stewart, and Carryer (2013) conducted research on EFT can reduce anxiety and improve academic performance in university students which discusses public speaking anxiety. The results showed a significant decrease in public speaking anxiety in students after being given EFT. When compared to some other interventions, hypno-EFT is an easy intervention and doesn't take a long time to do. Lataima, Ninuk and Puji (2020) who said that this intervention is an efficient and cost-effective intervention that can be carried out individually or in groups, independently by licensed practitioners or not. In addition, when compared with the intervention.

Due to the current state of a pandemic, researchers will conduct online interventions. In addition to making therapy easier, according to Mohamed and Griffiths (2020) online therapy (E-therapy) is currently affordable and effective for dealing with psychological and emotional stress at individual comfort. It will also strengthen online virtual care to help stop the virus from spreading. For EFT itself, it has been done online by Kalla (2016) whose research says that online EFT offers a useful alternative for residents of remote and rural areas who do not have access to mental health services and is very effective at keeping a positive mood.

Based on the background described above, the first hypothesis in this study is that hypno-EFT is effective in increasing self-confidence in 10th grade students majoring in office administration at SMK X Jakarta. Second, Hypno-EFT is effective in reducing public speaking anxiety in grade 10 students majoring in office administration at SMK X Jakarta.

\section{Research Method}

The research was conducted using an experimental research design with a pretest-posttest control group design model. The research subjects were 40 students of SMK X Jakarta. The research subjects were selected using purposive sampling with the criteria being grade 10 students majoring in office administration at SMK X Jakarta with low self-confidence and high public speaking anxiety. Subjects totaling 40 students were divided into two groups: the experimental group and the control group. The experimental group and the control group received a pre-test to determine the average value before the intervention was given. After that the experimental group received therapy while the control group did not receive intervention.

Pre-test, post-test, and intervention data collection is done online due to the Covid-19 pandemic. The intervention was carried out in 3 sessions, for 2 consecutive days plus 1 day after 2.5 months of intervention for follow-up. Each session was conducted using google meet. The duration of the intervention in each session was 15 minutes to 75 minutes. In the first session, the activities carried out were opening and introduction to hypno-EFT. In this first session, the subject filled out the informed consent. After that the research subjects introduced themselves, then were given material about hypno-EFT. In this session, the research subjects were given a homework assignment to practice hypno-EFT using the stages that have been shared. In the second session, the activities carried out were reviewing the material in the previous session, then doing hypno-EFT and doing post-test. The third session was 2.5 months after the second session was conducted. The activity carried out is to evaluate or follow up by giving a questionnaire. Research subjects are always present on time and in complete numbers. The hypno-EFT intervention was structured based on the steps from Gunawan (2010) which consisted of Preparation, The set up, The sequence, Nine gammut procedures, and Stage five.

The instruments used in this study were the self-confidence scale compiled by the researcher based on the characteristics of self-confidence according to Lautser (2008) and the public speaking anxiety scale adapted from Bartholomay and Houlihan (2016) based on the dimensions of public speaking anxiety. Before the confidence scale and public speaking anxiety scale were given, the researcher tried out the test kit. The content validity test was carried out by the supervisor as an expert judgment. In addition, based on a total of 
32 items on the self-confidence scale that was tested for item discrimination power, there were 9 items, the results obtained that the coefficient value was below 0.3 , then 9 items were eliminated. After the tryout, the confidence scale consists of 23 items and has a correlation range of 0.327-0.945. Based on the reliability test, a value of $0.919(\mathrm{P}>0.7)$ was obtained. This indicates a reliable self-confidence scale. The public speaking anxiety scale of all 17 items that were tested for item discrimination power contained 3 items with a correlation coefficient of less than 0.3 so the researchers discarded these items because they were considered to have poor item discrimination power. The final result obtained on the public speaking anxiety scale is that there are 14 items remaining which are stated to have good item discrimination power with a correlation number of $0.338-0.915$. For the results of the reliability test of the public speaking anxiety scale, a reliability coefficient of 0.941 is obtained. Therefore, it can be said that the scale used in this study is reliable.

\section{Results and Discussion}

Based on the self-confidence data analysis, a significance value of $0.000(p<0.05)$ was obtained with $t$ $=24.169$. These results indicate that there are changes before and after the administration of hypno-EFT, so as the basis for decision making in the independent sample t-test, it can be concluded that the hypothesis is accepted. Thus, it can be concluded that there is a change in the subject's level of confidence after being given hypno-EFT. This shows that hypno-EFT is effective in increasing self-confidence. The average confidence level of the experimental group and the control group were 72 and 46.50, respectively. This shows the mean difference score in the two groups of 25.5.

For the analysis of public speaking anxiety data obtained a significance value of $0.000(\mathrm{p}<0.05)$ with $t$ $=26.926$. These results indicate that there are changes before and after the administration of hypno-EFT, so as the basis for decision making in the independent sample t-test, it can be concluded that the hypothesis is accepted. Thus, it can be concluded that there is a change in the subject's level of public speaking anxiety after being given hypno-EFT. This shows that hypno-EFT is effective in reducing public speaking anxiety. The average level of public speaking anxiety in the experimental group and the control group was 26.75 and 42.15 , respectively. The results of hypothesis testing from the two data variables can be seen in the following table. This shows a mean difference score of 15.4 .

Table 1. Hypothesis Test Results

\begin{tabular}{ccc}
\hline Variabel & Sig. & T \\
\hline Kepercayaan Diri & 0.000 & 24.169 \\
Public Speaking Anxiety & 0.000 & 26.926 \\
\hline
\end{tabular}

In addition, to see the increase in self-confidence based on the results of the evaluation of behavior changes that have been carried out through the pre-test and post-test, it can be concluded that there is a significant change in the level of confidence possessed by the experimental group and tends to remain for the control group that is not treated. Before the intervention, the experimental group's confidence level was obtained an average of 45.80 which was at a low level. After the intervention, the average level of selfconfidence increased to 72.00. This shows that after being given the intervention the level of confidence in the experimental group is at a high level. Meanwhile for the control group the average level of confidence with the results of the pre-test and post-test were 45.85 and 45.45 , respectively. This shows that the control group's confidence level is at a low level.

Diagram 1 Evaluation of Changes in Confidence Level of the Experimental Group

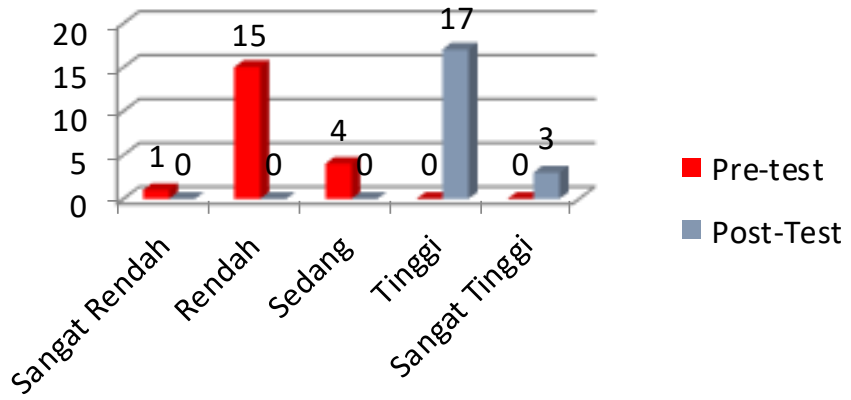


Diagram 2 Evaluation of Changes in Confidence Level of the Control Group

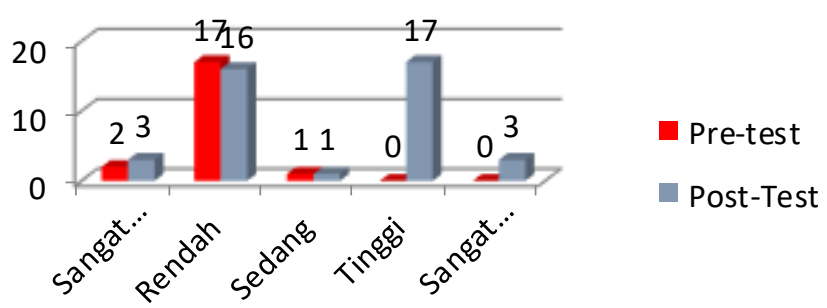

For public speaking anxiety, it can also be seen based on the results of the evaluation of behavior changes that have been carried out through pre-test and post-test. The results can be concluded that there is a significant change in the level of public speaking anxiety owned by the experimental group and tends to increase for the control group that is not treated. Before the intervention level of public speaking anxiety in the experimental group was obtained, an average of 43.00 was found at a high level. After the intervention, the average level of public speaking anxiety itself decreased to 26.75. This shows that after being given the intervention the level of confidence in the experimental group is at a low level. Meanwhile, for the control group, the average level of public speaking anxiety with pre-test and post-test results was 43.50 and 42.65 , respectively. This shows that the level of public speaking anxiety in the control group is at a high level.

\section{Diagram 3 Evaluation of Changes in the Experimental Group's Public Speaking Anxiety Level}

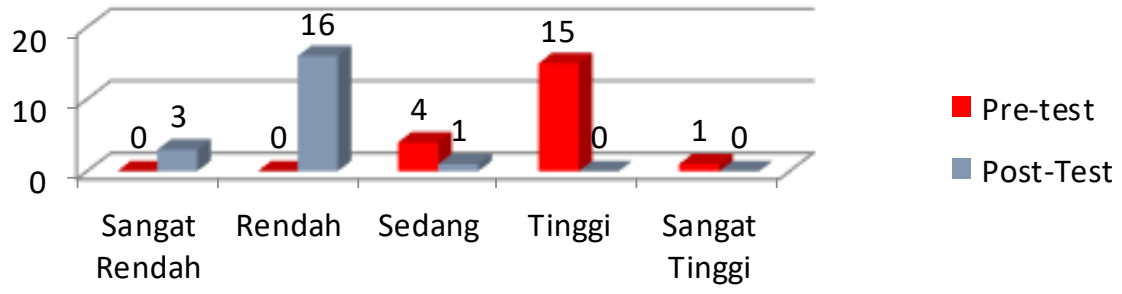

Diagram 4 Evaluation of Changes in the Control Group's Public Speaking Anxiety Level

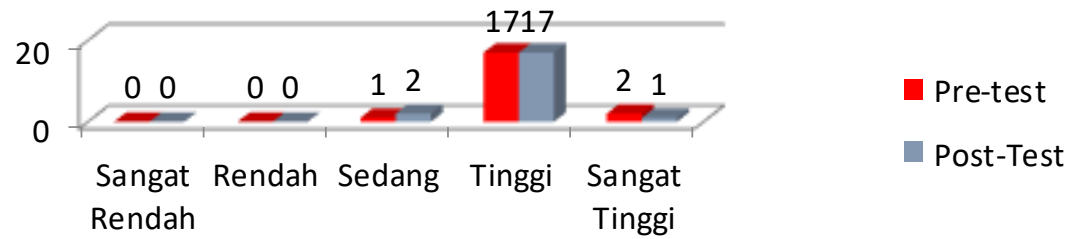


In this experiment, hypno-EFT works by stimulating the energy points scattered in the meridians by tapping. Church (2013) says tapping can calm the body, introduce non-traumatic physical stimuli, and interrupt emotional triggers that have been created by remembering the traumatic event. Pairing these memories with soothing physical stimulation can reduce their emotional intensity. Knocking signals the body that we are safe. After that, the nervous system no longer associates the memory with stress, anxiety or other negative conditions.

When hypno-EFT works by tapping, one can better understand aspects of the shift that are considered "random" consisting of old memories that have just emerged during the round of tapping. The neurons that fire together are then connected. One can better understand that when flooded with emotions by remembering past traumas, important parts of the brain will work less than optimally. This will lead to losing track of whether one is in the present or the past. This is why it is important to keep your eyes open and tap gently. This will help a person to stay in the present moment and prevent the memory from being traumatized again (Weiner, 2014). Thahir, Sulastri and Almurhan (2014) said that tapping on hypno-EFT helps improve circulation. Analogously, imagine meridians like rivers. Problems in emotions or physical are likened to garbage or rocks that block the flow of the river. The knock breaks the blockage that is blocking it. Knocking on the meridian points kinetic energy to the energy system and frees the barriers that block the flow of energy. Therefore, the experimental group felt a change in the level of self-confidence and public speaking anxiety experienced.

Giving hypno-EFT intervention is one of the right ways to increase self-confidence and reduce public speaking anxiety. This is in accordance with the opinion of Gunawan (2012) who said that hypno-EFT is effective in overcoming anxiety, fear, self-confidence problems, eliminating negative beliefs and others. Karatzias et al. (2011) also say hypno-EFT is a psychological intervention that can be easily taught and used alone. It also shows that hypno-EFT is an effective technique to increase self-confidence and reduce public speaking anxiety both individually and in groups. Gandari and I Gusti (2018) in their research also say that EFT is an intervention that is supported by empirical evidence, uses simple techniques, is easy to do by anyone, and does not have side effects.

Evaluation in this study was carried out 2.5 months after the intervention was carried out by filling out a questionnaire and open-ended questions for each subject in the experimental group. This is to find out whether positive changes persist or not and responses from the subject. The positive change achieved after the intervention, namely hypno-EFT, was effective in reducing public speaking anxiety and increasing selfconfidence in 10th grade students majoring in office administration at SMK X Jakarta. This can be seen based on the comparison of the average post-test and the average evaluation with scores for self-confidence 72.00 and 72.05, respectively. While for public speaking anxiety 26.75 and 26.05 . This shows that the average questionnaire remains at a high level of self-confidence and low public speaking anxiety. The students also gave answers that they felt less anxious and more confident when speaking in public. Hypno-EFT is still done by students with the reason that the method is easy and there are clear stages and it is allowed to see the stages.

\section{Conclusions and Suggestions}

Based on the results of the research conducted, it can be concluded that the two hypotheses proposed in this study are accepted, namely the first hypno-EFT is effective in increasing the self-confidence of 10th grade students majoring in office administration at Cyber X Jakarta Vocational School. Second, hypno-EFT is effective in reducing public speaking anxiety for 10th grade students majoring in office administration at SMK X Jakarta.

The advice given is that office administration students and teachers at SMK X Jakarta use hypno-EFT as an easy way to increase self-confidence and reduce public speaking anxiety. The school also provides information about the importance of self-confidence and public speaking for academic needs and in the world of work later. For future researchers, it is hoped that they can conduct research with different problems such 
as eliminating negative beliefs, insomnia, feelings of guilt, heartache and others. To see if there is a significant difference in the effectiveness of hypno-EFT on other problems. Future researchers can also do this with other intervention techniques in order to compare it with hypno-EFT. The researcher recommends that future research has a wider scope of research so that the results obtained can be maximized.

\section{References}

Bartholomay, E. M., \& Houlihan, D. D. (2016). Public Speaking Anxiety Scale: Preliminary psychometric data and scale validation. Personality and Individual Differences, 94, 211-215.

Boath. E., Stewart. A., \& Carrye. A. (2013). Tappingfor success: A pilot study to explore if emotional freedom techniques (EFT) can reduce anxiety and enhance academic performance in University students. Innovative Practice in Higher Education. 1(3), 1-13.

Cherry, K.(2010). The everything psychology book: An introductory guide to the science of human behaviour. Avon: Adams Media. Church. D. (2013). The EFT manual ( $3^{\text {rd }}$ Ed). Energy Psychology Press.

Cybermedia. (2019). Visi dan misi. Retrieved, june 20,2021 https://www.cybermedia.sch.id/read/3/visi-dan-misi

Data pokok kementrian pendidikan dan kebudayaan .(2021). Rekapitulasi Data Pokok Pendidikan Nasional. Retrieved, June 20, 2021. https://dapo.kemdikbud.go.id/

Gunawan, A. W. (2009). Hypnotherapy workbook. Surabaya: Quantum Hypnosis Indonesia

Gunawan. A.W. (2012). The secret of mind set. Jakarta : PT. Gramedia Pustaka Utama.

Indrawati, E. (2018). Improving self confidence of adolesense through counseling directive. International Journal of Science and Research (IJSR). 7, 373-375.

Juwita, S., Ivan, M.A., \& Rosy, R. (2011). Hubungan antara kepercayaan diri dengan kecemasan berbicara di depan umum pada mahasiswa. Personifikasi. 2(2), 103-109.

Kalla, M. (2016). Supporting healthcare chronic disease through remote emotional freedom techniques (EFT) treatment and selfcare: An Evaluation using the WHO determinants of health. Energy Psychology: Theory, Research, and Treatment. 8 (1), 55-66.

Karatzias, T., Power, K., Brown, K., McGoldrick, T., Begum, M.B., Young, J., Loughran, P., Chouliara Z., \& Adams, S. (2011). A Controlled Comparison of the Effectiveness and Efficiency of Two Psychological Therapies for Posttraumatic Stress Disorder. Journal of Nervous and Mental Disease. 199 (6), 372 - 378.

Kementrian Pendidikan dan Kebudayaan Republik Indonesia. Retrieved August, 4, 2019 https://www.kemdikbud.go.id/kemdikbud/dokumen/Paparan/Paparan\%20Wamendik.pdf .

Lataima, N.S., Ninuk, D.K., \& Puji, A. (2020). Manfaat emotional freedom technique (EFT) bagi pasien gangguan kecemasan. Jurnal penelitian kesehatan suara FORIKES. 11, 129-132.

Mohamed, N.H., \& Griffiths, S. (2020). Online therapy during the covid-19 pandemic. Online international article of covid-19 pandemics, 1 psych-care. 1-5.

Peraturan PemerintahNomor 29 Tahun 1990. Retrieved August, 4, 2019. http://www.bphn.go.id/data/documents/90pp029.pdf.

Raja, F. (2017). Anxiety level in students of public speaking: Causes and remedies. Journal of Education and Educational Development. 4, 94-110.

Rakhmat, J. (2009). Psikologi komunikasi. Bandung: Remaja Rosda Karya.

Thahir, A., Sulastri., Almurhan. (2014). Emotional freedom technique. Jurnal kesehatan.5(1), 84-89.

Wahyuni, $\quad$ E. (2015.) $\quad$ Hubungan $\quad$ Self-Effecacy dan Keterampilan dengan Kecemasan Berbicara di Depan Umum, Jurnal Komunikasi Islam, vol. 5 no. 1 , hal. 51-82.

Weiner, G. (2014). How trauma alters memory; why every eft practitioner should know about the amygdala and hippocampus. The Art and Science of EFT, Retrieved September, 25, 2021 From https://www.efttappingtraining.com/eft-article/howtrauma-alters-memory-eft-amygdala-hippocampus/ 